\title{
Investigación sobre la actividad puzolánica de materiales de desecho procedentes de arcilla cocida
}

\author{
Research about the pozzolanic activity of waste materials from \\ calcined clay
}

M. I.SÁNCHEZ de ROJAS ${ }^{\star}$, M. FRÍAS ${ }^{\star}$, J. RIVERA ${ }^{\star}$,M.J.ESCORIHUELA*y F.P.MARÍN**

${ }^{(\circ)}$ (Instituto de Ciencias de la Construcción Eduardo Torroja-CSIC)

(") (ITECE.GrupoUralita)

Fecha de recepción: 22-III-00

Fecha de aceptación: 10-VII-00

ESPAÑA

RESUMEN

Para llevar a cabo labores encaminadas al reciclado $y$ revalorización de residuos es necesario un conocimiento profundo de los mismos, de forma que se busquen aplicaciones concretas de uso.

El objetivo de este estudio es investigar la posibilidad de utilizar materiales de desecho procedentes de arcilla cocida, concretamente teja cerámica, una vez triturada y molida, como puzolana. Para ello, se efectúan diferentes ensayos dirigidos a establecer la actividad puzolánica del material. A su vez, estos resultados son comparados con otros residuos industriales, ceniza volante y humo de silice, habituales en la elaboración de morteros y hormigones.

\section{SUMMARY}

To recycle and reutilise waste materials and find definite applications for their use, it is necessary to have a deep knowledge of them.

The aim of this study is to study the possibility of using waste materials from calcined clay, actually ceramic tile, once crushed and grounded, as pozzolanic material. For this purpose, different tests are carried out in order to establish the pozzolanic activity of this material. At the same time, these results are compared to those of other industrial by-products, fly ash and silica fume, which are pozzolanic materials usually employed to elaborate mortars and concretes.

\section{INTRODUCCIÓN}

El aprovechamiento y revalorización de productos generados en procesos industriales tiene que adquirir mayor prioridad en el futuro, por distintas razones: consumo energético, gasto en materias primas y mano de obra, necesidad de vertederos controlados, y, sobre todo, deterioro medioambiental, provocado por el aumento progresivo de residuos.

Por este motivo, han surgido, a nivel mundial, iniciativas para controlar y regular la gestión de los

\section{INTRODUCTION}

The utilization and revaluation of industrial byproducts have to acquire greater priority in the future because of different reasons: energy cost, expense of raw materials and manual labour, need of controlled sinks and mainly, environmental decay produced by the progressive increase of all types of waste-materials.

For this reason, different worldwide initiatives have appeared to control and regulate the management 
desechos industriales, así como de los materiales procedentes de demoliciones. Cada vez existirán regulaciones más estrictas, que repercutirán económicamente a favor de opciones, poco frecuentes hoy en día, como son la minimización y reciclado de residuos.

De cualquier modo, todas estas acciones pasan por un mayor conocimiento de los materiales de desecho, buscando aplicaciones concretas de uso que sean factibles con sus características.

En España se fabrican más de 21 millones de toneladas de materiales cerámicos (ladrillos, tejas, boverillas, bloques, etc.) de los cuales, 1, 2 millones corresponden a tejas de arcilla cocida. El porcentaje de productos rechazados para la venta, y por tanto de desecho, se acerca al $5 \%$, lo que constituye un volumen importante de residuos.

En este trabajo se plantea el aprovechamiento de productos de desecho procedentes de materiales de arcilla cocida, para su reutilización en morteros y hormigones como posibles materiales puzolánicos. Es sabido que uno de los primeros materiales utilizados como puzolanas eran las arcillas térmicamente tratadas, material semejante a los prefabricados de arcilla cocida, cuyos desechos de fabricación son base de esta investigación.

Los materiales puzolánicos, cuando son incorporados en cementos y hormigones, mitigan algunas de las desventajas que acompañan a los cementos portland tradicionales $(1,2)$, como son la liberación de gran cantidad de hidróxido cálcico, la posibilidad de reacciones de carácter expansivo y, sobre todo, el carácter fuertemente exotérmico de las reacciones de hidratación.

Las reacciones que tienen lugar en la hidratación del cemento son exotérmicas y, por tanto, provocan un calentamiento de la masa de cemento. Esta variación de temperatura, desde los momentos iniciales de fraguado hasta el endurecimiento del cemento, es causa de retracciones, que, a su vez, dan como resultado el agrietamiento observado en algunas obras de construcción que emplean grandes masas de hormigón o en estructuras en las que se utilizan mezclas ricas en cemento (3). Por este motivo, el control y medida del calor de hidratación es objeto de atención de numerosos trabajos de investigación, algunos de ellos realizados por los autores del presente escrito (4) (5) (6).

La cinética de la reacción puzolánica se investiga siguiendo metodologías de carácter químico y calorimetría Langavant, con las que se consigue of industrial wastes and the materials from demolitions. In this way, the legal restrictions will be stricter to minimize and recycle these whaste products.

However, all these actions involve a deeper knowledge of the waste materials, finding definite applications.

In Spain, 21 millions tons of ceramic materials (bricks, tiles, vaults, blocks, etc.) are manufactured of all these, 1,2 millions correspond to calcined clay tiles. The percentage of rejected products for selling (waste materials) is about $5 \%$, constituting a considerable amount of waste product.

In this work, the utilization of waste materials from calcined clay as pozzolanic material to manufacture mortars and concretes is studied. Its is known one of the first materials used as pozzolans were thermal treated clays, material similar to the calcined clay precast elements, whose wastes are the base of this research.

Pozzolanic materials, when are incorporated in cement and concretes, reduce some of the disadvantages of the traditional Portland cements ( 1 , 2) as the large release of calcium hydroxide, the possibility of expansive reactions and, mainly, the great exothermal character of the hydration reactions.

Reactions take place in the cement hydration process are exothermal reactions that cause a heating of the cement paste. This temperature variation, from the first moments of setting until the cement hardening, is the cause of shrinkage that leads to cracks, observed, sometimes, in construction works of large concrete amounts or structures with cement-rich mixes (3). For this reason, the control and measurement of hydration heat is the aim of numerous research works, some of them carried out by the authors of the present work $(4,5,6)$.

The kinetics of pozzolanic reaction is investigated following chemical methods and Langavant calorimetry in order to establish the relationship 
establecer la relación entre actividad puzolánica de los materiales y desarrollo de calor en el tiempo. Los resultados obtenidos son comparados con otros residuos industriales, tradicionalmente utilizados en el sector de la construcción, como son las cenizas volantes y el humo de sílice.

\section{ESTUDIOSEXPERIMENTALES}

\section{. Materiales}

Material a base de arcilla cocida.

Las muestras proceden de la trituración y molienda de tejas cerámicas. Estos materiales de arcilla cocida tienen una composición química semejante a otros residuos industriales con propiedades puzolánicas, como son la ceniza volante y el humo de sílice (Figura 1). Todos ellos presentan un fuerte carácter ácido, con predominio de la sílice y la alúmina e incluso el óxido de hierro. between pozzolanic activity and heat development with time. The results obtained are compared to those of other industrial by-products traditionally used in construction such as fly ashes and silica fume.

\section{EXPERIMENTAL}

\section{- Materials \\ Material constituted by calcined clay.}

Samples come from the crushing and grinding of ceramic tiles. These materials have a chemical composition similar to other industrial by-products as silica fume and fly ash (Figure 1). All of them present a marked acid character with alumina and silica as main components and also iron oxide.

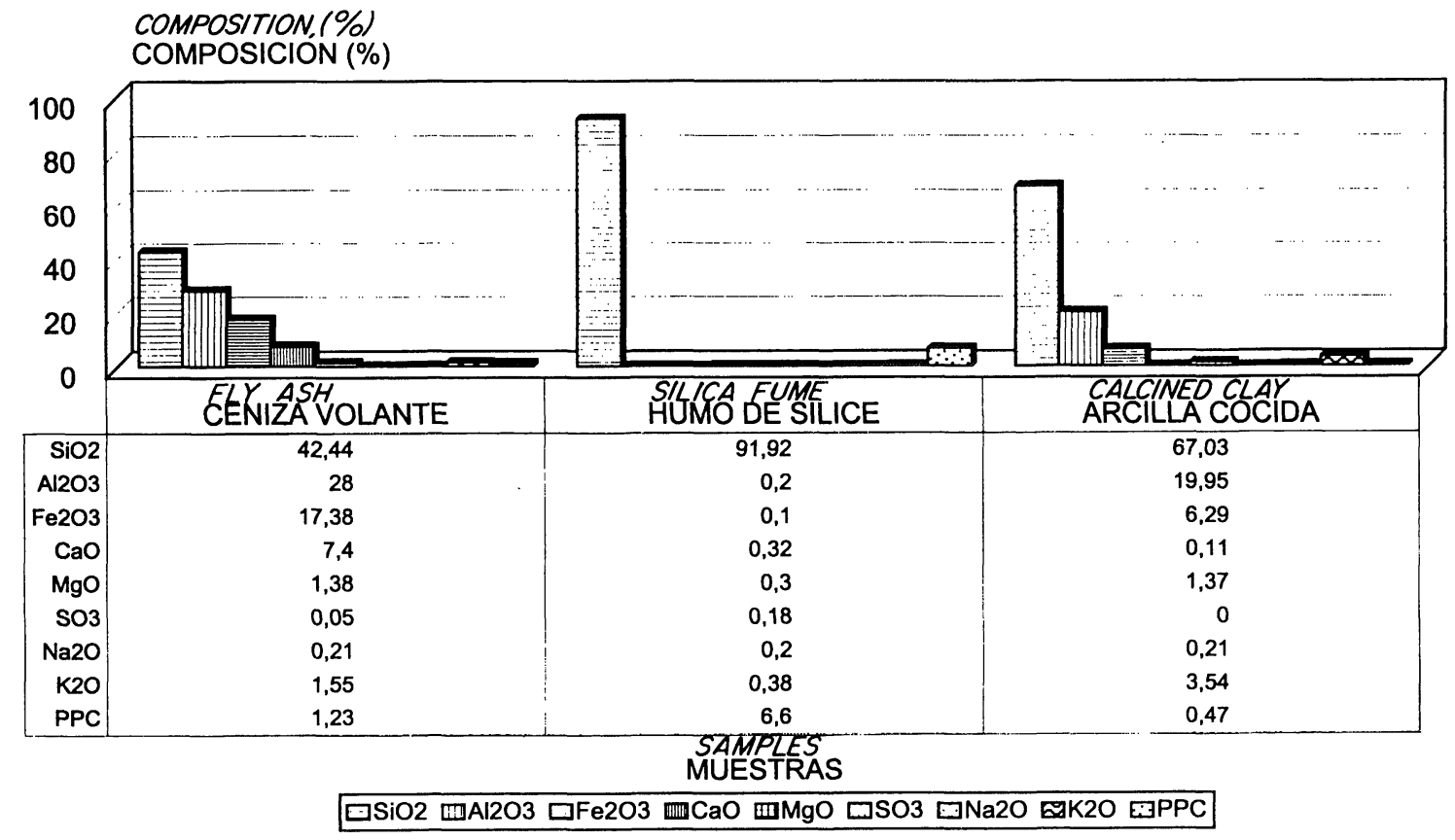

Figura 1.- Composición química.

Figure 1.- Chemical composition.

\section{- Métodos}

\section{1.- Disolución saturada de cal}

Estudio de la actividad puzolánica mediante disolución saturada de cal.

La evaluación de la actividad puzolánica de los materiales se realiza mediante un método acelerado, en

\section{- Methods}

\section{Lime saturated solution}

Study of the pozzolanic activity through lime saturated solution method.

The evaluation of the pozzolanic materials activity is determined by means of an accelerated method that 
el que se estudia la reacción del material con una solución saturada de cal en el tiempo (Figura 2). La cal fijada por la muestra (mM/L) se obtiene por diferencia de la concentración de la solución saturada de cal inicial y el $\mathrm{CaO}$ presente en la solución en contacto con la muestra, al final de cada período prefijado.

\section{2.- Estudio de Fratini}

Se trata de un método para evaluar la puzolanicidad de los cementos puzolánicos $\mathrm{y}$, por tanto, determinar el comportamiento como puzolana de un material, cuando éste es añadido al cemento en una determinada proporción. Este método está recogido en la Norma EN 196-5 (7) (Figura 3).

Para comprobar el efecto que tiene el material de arcilla cocida en un cemento, se preparan mezclas: cemento/ material de arcilla, en las siguientes proporciones: $100 / 0,90 / 10$ y $80 / 20$.

Las edades de ensayo consideradas son 7 y 28 días respectivamente, tal y como establecía la norma mencionada en versiones anteriores, en vez de 8 y 15 días que marca la versión actual. Esta variación en el tiempo de ensayo se lleva a cabo para unificar las edades y poder establecer conclusiones.

El cemento portland, utilizado como referencia, es un CEM I/42. 5 según la designación de la norma española UNE 80301 (8), que presenta un contenido en clínker igual o superior al $95 \%$, y que puede llevar incorporados otros componentes adicionales hasta el $5 \%$. studies the reaction of the material the fixed lime with a saturated lime solution (Figure 2). Lime fixed by the sample $(\mathrm{mM} / \mathrm{l})$ is obtained by difference between the initial concentration of saturated lime solution and the $\mathrm{CaO}$ present in the solution in contact with the sample, at the different fixed periods.

\section{Fratini study}

This is a method to evaluate the pozzolanity of cements and to determine the behaviour of a material as a pozzolan when this is added to cement in a determined proportion. This method is collected in the EN 196-5 Standard (7) (Figure 3).

To verify the effect of the calcined clay material in a cement, the following mixes are prepared: cement/clay material in the following proportions: 100/0, 90/10 and $80 / 20$.

The test ages considered are 7 and 28 days as it is established in the previous Standard instead of 8 and 15 days considered by the updated Standard. This variation in the times is taken in order to compare the samples and establish conclusions.

The Portland cement used, as reference, is a CEM I/42. 5 according to Spanish Standard UNE 80301 (8), with a clinker content of $95 \%$ and up to $5 \%$ of additional components.

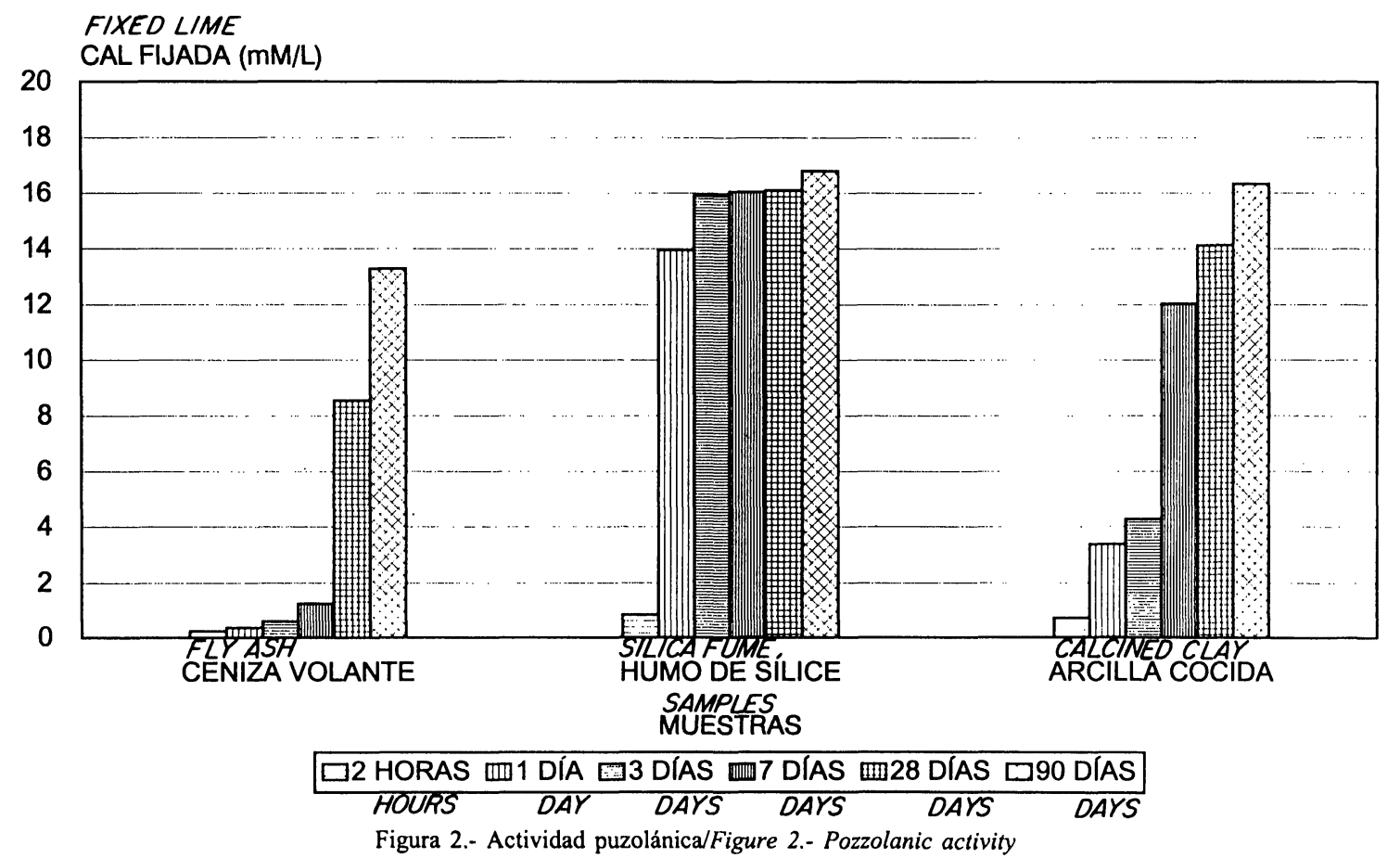




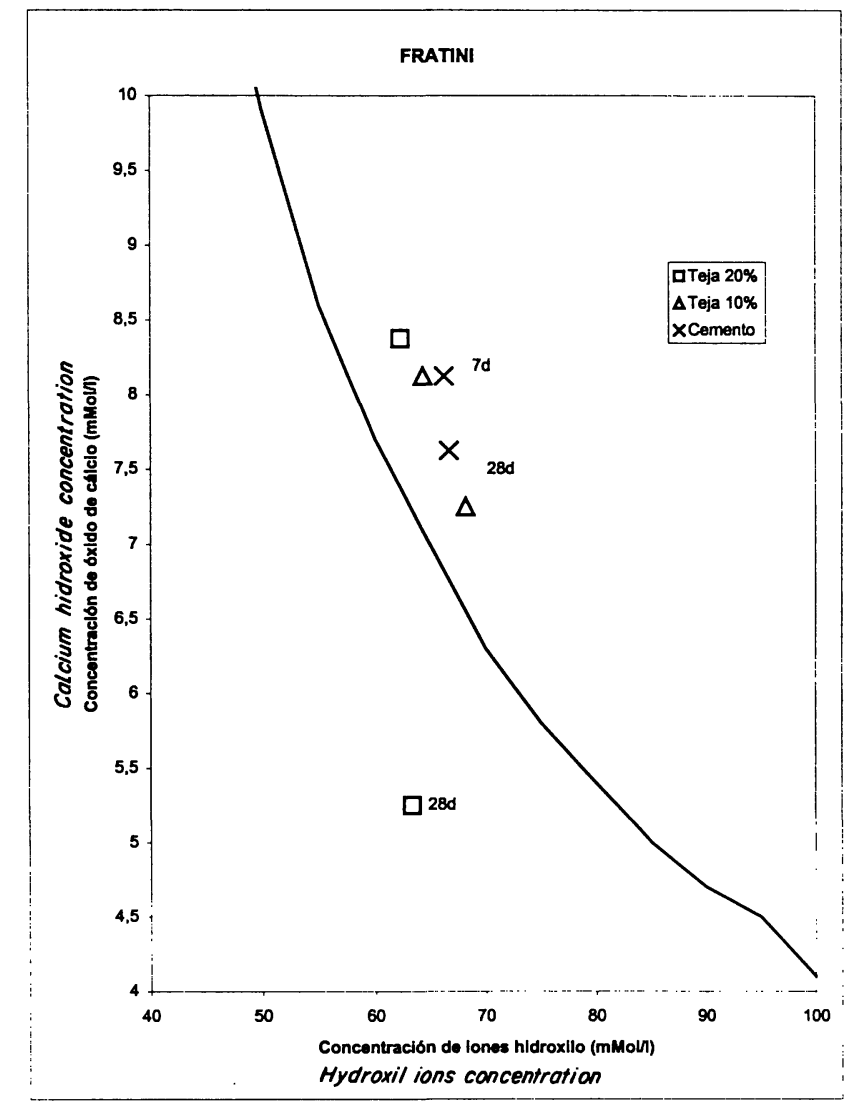

Figura 3.- Ensayo Fratini.

Figure 3.- Fratini test.

\section{3.- Calor de hidratación}

El método recogido en la normativa española (9) es el Calorímetro de Langavant (10). Este método semiadiabático consiste en la cuantificación del calor generado en la hidratación del cemento, utilizando como calorímetro un vaso de Dewar o, más exactamente, una botella térmicamente aislante.

Para ello, se confecciona con el cemento objeto de estudio un mortero que se coloca en un bote cerrado, que, a su vez, se introduce en la botella aislante. El calor desarrollado por este mortero durante el curso de la hidratación se compara con la de un mortero térmicamente inerte (amasado con anterioridad, por lo menos desde tres meses antes del ensayo, según la norma mencionada) y contenido en otra botella aislante utilizada como patrón o testigo.

En la elaboración de los morteros, la arena empleada es de origen silícico, con un contenido de sílice superior al $98 \%$ y un tamaño de partícula menor a $2 \mathrm{~mm}$. La proporción cemento/arena es $1 / 3$ y la relación agua/cemento de 0,5 .

\section{Heat of hydration}

The collected method in the Spanish Standard (9) is the Langavant calorimeter (10). This semi-adiabatic method consists of the quantification of the heat released in the cement hydration, using as calorimeter a Dewar vessel or more exactly thermal insulated bottle.

For this purpose, a mortar is prepared with the cement-mixed and it is placed in a sealed beaker that is introduced in an insulated bottle. The heat developed by this mortar during the hydration process is compared to that of a thermally inert mortar (formerly mixed, at least three months before the test, according to the mentioned Standard) and contained in another bottle used as reference.

In the manufacturing mortar, the sand used is of siliceous origin with silica content higher than $98 \%$ and a particle size lower than $2 \mathrm{~mm}$. The cement/sand ratio is $1 / 3$ and the water/cement ratio is 0.5 . 
Las muestras analizadas son:

Cemento de referencia: proporción cemento/material de arcilla: $100 / 0$

Cemento de arcilla: proporción cemento/material de arcilla: $80 / 20$

\section{RESULTADOS}

Los materiales procedentes de arcilla cocida, finamente molidos (3.500-4.000 unidades Blaine), presentan una actividad puzolánica destacable, si los comparamos con otros subproductos industriales habituales en el sector de la construcción. Así, en la Figura 2, se puede observar cómo la teja de arcilla tiene una actividad superior a la ceniza volante, residuo procedente de las centrales termoeléctricas que utilizan carbón como combustible.

Sin embargo, los productos de arcilla cocida a primeras edades no alcanzan al humo de sílice, subproducto de la fabricación del ferrosilício, que sigue siendo el producto estrella en cuanto a la alta actividad a edades tempranas y cuyos resultados, junto con los de la ceniza volante, han servido de referencia (Figura 2).

La escasa actividad puzolánica de los materiales de arcilla cocida, a primeras edades, queda igualmente reflejada en los estudios efectuados mediante el ensayo de puzolanicidad (Fratini), donde los cementos mixtos elaborados no son puzolánicos hasta la edad de 28 días en el caso de la mezcla 80/20 (Figura 3).

También, se obtienen resultados análogos por calorimetría Langavant, en los que se comprueba cómo el material de arcilla cocida rebaja en todo momento el calor desarrollado durante el proceso de hidratación del cemento mixto elaborado (cemento/ material de arcilla:80/20), como queda recogido en la Figura 4 y, más claramente, en la Figura 5.

En la Figura 5, se representa el incremento de calor, positivo o negativo, experimentado por los cementos

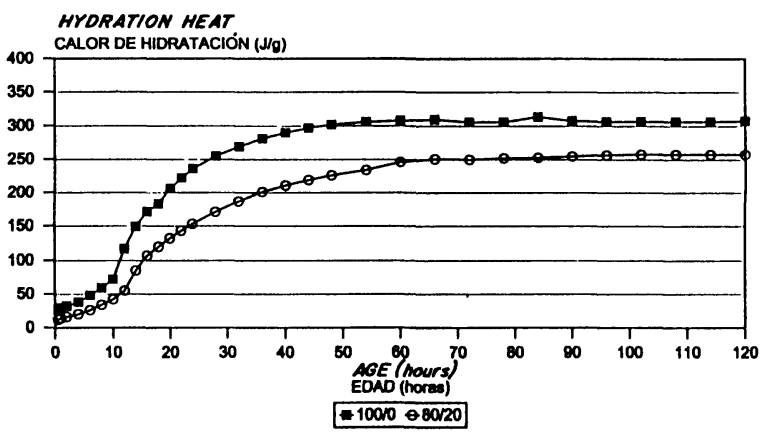

Figura 4.- Evolución del calor de hidratación. Figure 4.- Evolution of the heat of hydration.
Samples analysed are:

Reference cement: cement/clay material ratio: 100/0

Clay cement: cement/clay material ratio: $80 / 20$

\section{RESULTS}

The materials from calcined clay, finely ground (3.500-4.000 Blaine units), present a remarked pozzolanic activity when they are compared to other industrial by-products used in building materials. Thus, in Figure 2, it is observed how the clay tile has a higher activity than that of a fly ash.

However, the calcined clay materials have lower activity at first ages than silica fume that has the highest activity at these ages (Figure 2).

The small pozzolanic activity of the calcined clay materials at first ages is also seen in the study carried out by Fratini test, where the mixed cements prepared are not pozzolanic until 28 days in the case of the mixture 80/20 (Figure 3).

Also, similar results are obtained by Langavant calorimetry, in which it is verified that the calcined clay decreases the heat developed during hydration of the mixed cement (cement/clay material: 80/20), as it is shown in Figure 4 and, more clearly in Figure 5.

In Figure 5, it is shown the heat increase, positive or negative, underwent by the mixed cements with

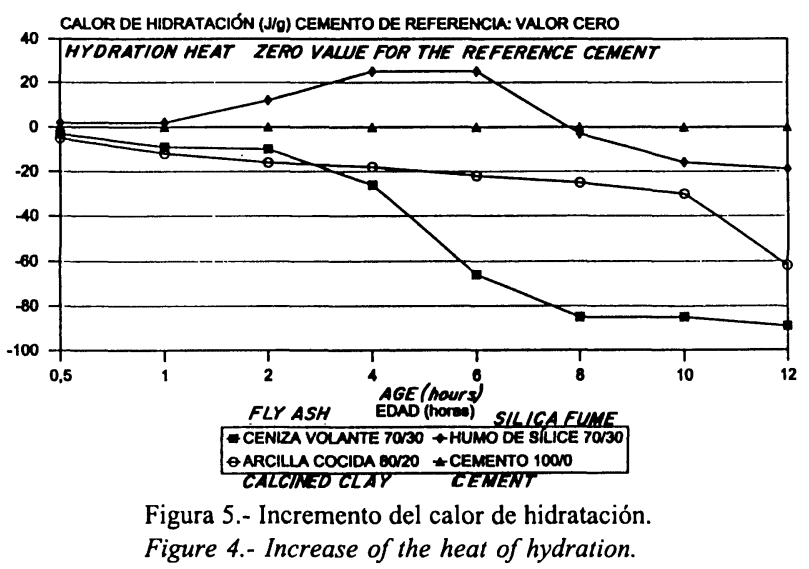

Figure 4.- Increase of the heat of hydration. 
mezcla con relación al cemento de referencia, que se considera valor cero.

Como puede observarse la ceniza volante y el material de arcilla presentan valores negativos en el calor de hidratación, hecho contrario al que provoca el humo de sílice de alta actividad puzolánica. Este producto, investigado en trabajos previos (5), provoca un aumento en el calor de hidratación, en relación al cemento base. Este incremento se debe a la reacción cal-puzolana débilmente exotérmica, que, en el caso del humo de sílice, es capaz de aumentar el calor desprendido, de forma que prevalece la reacción puzolánica sobre el grado de sustitución de cemento.

Por lo tanto, el material de arcilla cocida presenta actividad puzolánica, pero el calor desarrollado en esta reacción no es capaz de incrementar el calor desprendido por la hidratación del cemento, disminuyendo este calor en un porcentaje similar al de sustitución de cemento por material de arcilla en la mezcla preparada. Así, en el punto máximo de calor desarrollado, aproximadamente a las 24 horas, la reducción de calor del cemento $80 / 20$ es del $19 \%$ con respecto al cemento base.

\section{CONCLUSIONES}

. Los estudios efectuados indican la viabilidad de utilización de estos materiales de desecho de arcilla cocida como puzolanas y sustitutivo parcial del cemento.

- La actividad puzolánica a primeras edades sería superior, en líneas generales, a las cenizas volantes, pero inferior al humo de sílice

. Los cementos mixtos (80/20), según el ensayo normalizado (puzolánicidad de Fratini), no serían considerados cementos puzolánicos hasta la edad de 28 días.

- El calor desarrollado en la hidratación del cemento con un $20 \%$ de arcilla cocida, es inferior al cemento base, ya que predomina el efecto de sustitución de cemento, sobre la actividad puzolánica del material. La disminución de calor es proporcional al grado de incorporación de teja cerámica.

\section{AGRADECIMIENTOS}

Esta investigacione ha tenido lugar gracias a un Proyecto de Investigación (AMB96-1095) subvencionado por la Comisión Interministerial de Ciencia y Tecnología (CICYT), así como a la colaboración de la División de Tejas del Grupo Uralita. respect to the reference cements considered as cero.

As it is observed, fly ash and clay material present negative values in the heat of hydration, oppositely to that of the silica fume with higher pozzolanic activity. This product, formerly studied (5) provokes an increase in the heat of hydration with respect to the reference cement. This increase is due to the lime-pozzolan reaction, weakly exothermal, that, in the case of silica fume is able to increase the heat released, prevailing the pozzolanic reaction over the cement substitution degree.

Thus, the calcined clay material present a pozzolanic activity, but the heat developed in this reaction is not able to increase the heat released in the cement hydration, decreasing this heat in a percentage similar to that of the cement substitution by the clay in the mixture. So, in the maximum heat, at about 24 hours, the reduction of heat of the cement $80 / 20$ is $19 \%$ with respect to the reference cement.

\section{CONCLUSIONS}

. The studies carried out indicate the viability of using these waste materials from calcined clay as pozzolans and partial sustitutive of cement.

- The clay pozzolanic activity at first ages is higher, in general, than that of fly ashes, but lower than silica fume activity.

- Blended cements (80/20), according to the Standard test (Fratini pozzolanity), will be considered as not pozzolanic until 28 days.

- The heat developed in the cement hydration with a $20 \%$ of calcined clay is lower than that of reference cement, because the cement substitution effect is stronger than the pozzolanic activity of the material. The heat decrease is proportional to the incorporation degree of the ceramic tile.

\section{ACKNOWLEDGMENTS}

This research has been funded through a Research project (AMB96-1095) of the Comision Interministerial de Ciencia y Tecnologia (CICYT), also thanks to Tile Division of Uralita Group for its contribution in this research. 


\section{BIBLIOGRAFÍA}

(1)J.CALLEJA: “Las puzolanas". Ión, Ns. 340, 341, 343 y 344, noviembre y diciembre(1969), febrero y marzo (1970), 623-638, 700-713, 81-90, 154-160.

(2)F. SORIA: "Las puzolanasy el ahorro energético en los materiales de construcción. Materiales de Construcción, N.190-191,69-84(1983).

(3)R. SPRINGENSCHMID: "Cracks in Concrete Caused by the Heat of Hidration". Zement Kalk Gips, N. 3, 132-138 (1991).

(4)M.I. SÁNCHEZ DE ROJAS; M.P. LUXÁN; M. FRÍAS; N. GARCÍA:”The influence of different additions on portland cement hydration heat". Cement and Concrete Research, V. 23, N.1, 46-54 (1993).

(5)M.I. SÁNCHEZ DE ROJAS; M. FRÍAS: "The influence of silica fume on the heat of hydration of portland cement". Fifth CANMET/ ACI Int. Conference Fly Ash, Silica Fume, Slag and Natural Pozzolans in Concrete. Vol. 2, 829-843. Milwaukee, Wisconsin, EEUU(1995). (6)M. FRÍAS, M.I. SÁNCHEZ DE ROJAS, J. CABRERAS “Effect of Metakaolin pozzolanic activity on the evolution of hydration heat in mortar". Cement and Concrete Rescarch, V. 30, 209-216 (2000).

(7)Norma EN 196-5 (UNE 80-280: "Mćtodos de ensayos de cementos. Ensayo de puzolanicidad para cementos puzolánicos".

(8)Norma UNE 80301 : “Cementos. Definiciones, Clasificación y Especificaciones".

(9)Norma UNE 80118 : "Métodos de Ensayo de Cementos. Ensayos Físicos: Determinación del Calor de Hidratación por Calorimetría Semiadiabática (Método del Calorímetro de Langavant)".

(10)R. ALEGRE: "La Calorimétrie des Ciments au CERILH". Revue des Matériaux, (547), 218-229. (548), 247-262 (1961).

\section{Publicaciones del Instituto Eduardo Torroja - CSIC}

\section{Números monográficos de INFORMES}

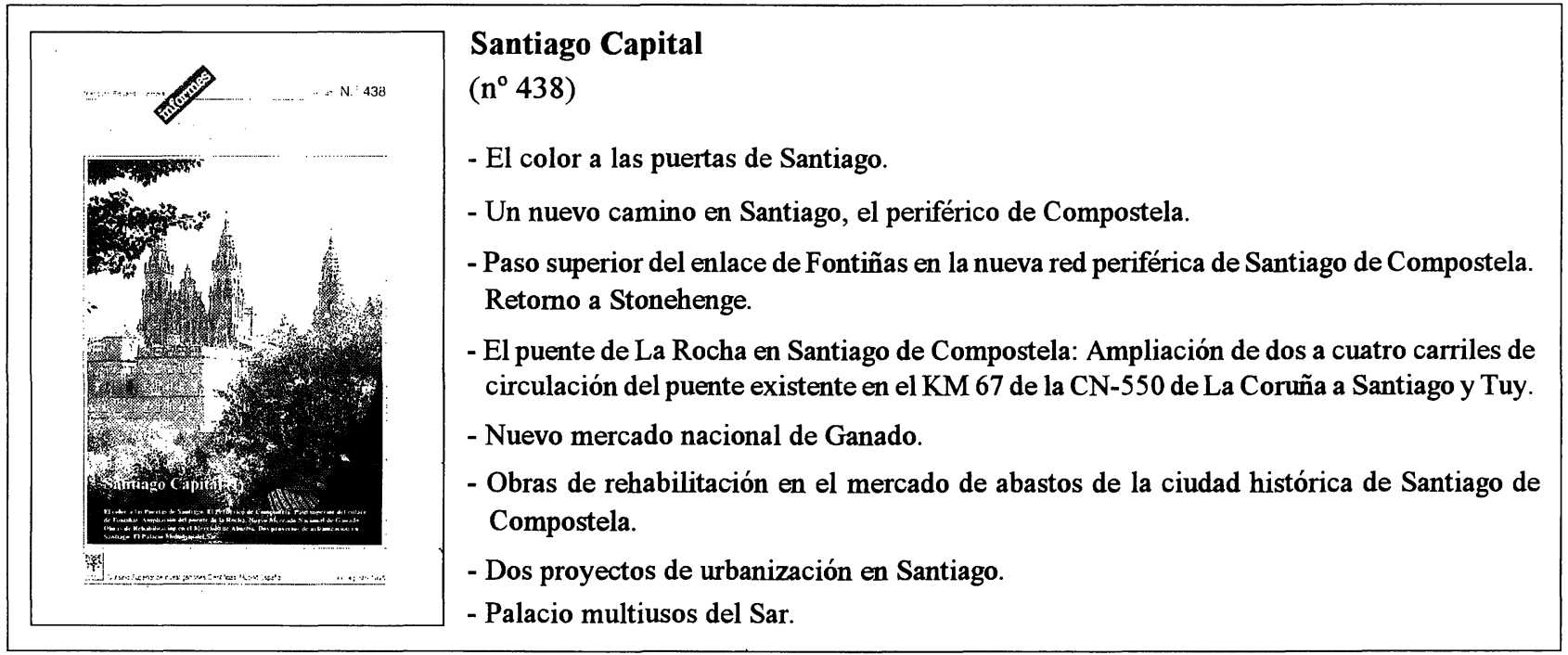

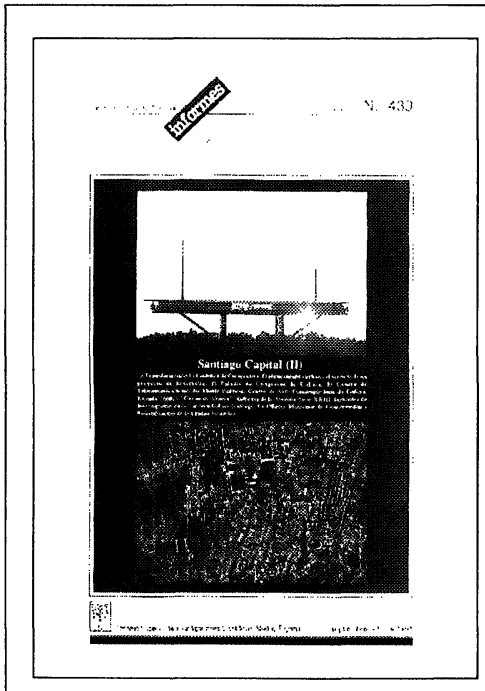

$\left(n^{\circ} 439\right)$

- La transformación urbanística de Compostela. El planeamiento urbano al servicio de un proyecto de desarrollo (Galicia-España).

- Palacio de Congresos y Exposiciones de Galicia en Santiago (Galicia-España).

- Nueva instalación de Telecomunicaciones. Santiago de Compostela (Galicia-España).

- Centro de Arte Contemporáneo de Galicia en Santiago de Compostela (Galicia-España).

- Escuela Pública "Carme de Abaixo". Santiago de Compostela (Galicia-España).

- Avenida Xoan XXIII. Santiago de Compostela (Galicia-España).

- Edificios para Instituto de Investigación de la Universidad de Santiago. Santiago de Compostela (Galicia-España).

- La Oficina Municipal de Conservación y Rehabilitación de la Ciudad Histórica de Santiago de Compostela (Galicia-España). 